\title{
Analisa Pola Belanja Swalayan Daily Mart Untuk Menentukan Tata Letak Barang Menggunakan Algoritma FP-Growth
}

\author{
Kezia Sumangkut $^{(1)}$, Arie Lumenta ${ }^{(2)}$, Virginia Tulenan ${ }^{(3)}$ \\ Teknik Informatika, Universitas Sam Ratulangi, Manado, Indonesia. \\ Email: ksumangkut@gmail.com, al@unsrat.ac.id, virginia.tulenan@gmail.com
}

\begin{abstract}
Abstrak --- Perkembangan pasar modern yang semakin hari semakin pesat dapat dilihat dari pusat perbelanjaan seperti supermarket, minimarket, grosir, dan lain sebagainya yang dibangun untuk kebutuhan melayani konsumen. Dan pemanfaatan data transaksi yang banyak dapat memberikan pengetahuan yang menarik dalam membuat kebijakan dan strategi penempatan rak barang. Maraknya perbelanjaan modern dan pesaing bisnis seperti itu tidak lepas dari peralihan pola pikir konsumen yang tadinya mencari harga yang murah, kini sudah memperhatikan aspek keamanan, kebersihan, kenyamanan, keramahan dalam pelayanan serta kelengkapan jenis barang dan penempatan rak barang. Oleh karena itu dalam penelitian ini, penulis mengangkat permasalahan tentang Analisa Pola Belanja Swalayan Daily Mart Untuk Menentukan Tata Letak Barang Menggunakan Algoritma FP-Growth, dalam pelayanan yang sering terjadi di swalayan Daily Mart, dan untuk mewujudkan hal itu penulis menerapkan metodologi KDD (Knowledge Discovery in Database).

Salah satu teknik Data Mining dalam penelitian ini adalah Association Rule dalam Java Weka untuk mencari pengetahuan pola dari pembelian konsumen. Hasil dari penelitian ini berupa data pola pembelian/struk yang memiliki nilai confidence yang tinggi sebagai bahan untuk merekomendasi tata letak sesuai banyak barang yang paling sering dibeli.
\end{abstract}

Kata Kunci --- Data Mining, Association Rules, Market Based Analysis, Java Weka

\section{PENDAHULUAN}

Swalayan Daily Mart adalah suatu usaha yang setiap harinya memiliki banyak data mulai dari data pembelian, data penjualan maupun data transaksi oleh karena itu seiring dengan kemajuan Teknologi Informasi yang pesat menghadirkan tingkat kompetensi yang semakin ketat membuat para pelaku bisnis harus berpikir keras dalam menyusun strategi untuk menghadapi persaingan tersebut.

Perkembangan pasar modern yang semakin maju dapat dilihat dari pusat perbelanjaan misalnya swalayan Daily Mart, supermarket, minimarket, grosir dan lain sebagainya yang dibangun untuk kebutuhan melayani konsumen. Maraknya perbelanjaan modern seperti itu tidak lepas dari peralihan pola pikir konsumen yang tadinya mencari harga yang murah, kini sudah memperhatikan aspek keamanan, kebersihan, kenyamanan, keramahan dalam pelayanan serta kelengkapan jenis barang dan penempatan rak barang. Dalam penelitian ini, penulis mengangkat permasalahan dalam pelayanan yang sering terjadi di swalayan Daily Mart, yakni pemilik ini cenderung masih menempatkan barang tanpa memperhatikan hubungan antar barang yang diinginkannya. Berdasarkan latar belakang masalah tersebut, diharapkan terbentuk pola yang dapat digunakan sebagai landasan pengambilan keputusan untuk dapat meningkatkan penjualan melalui penempatan produk

Dan untuk mewujudkan hal itu penulis mngangkat permasalahan tentang Analisa Pola Belanja Swalayan Daily Mart Untuk Menentukan Tata Letak Barang menggunakan Algoritma FP-Growth.

\section{II.LANDASAN TEORI}

\section{Pola Belanja Konsumen}

Menurut Kamus Besar Bahasa Indonesia Pola Belanja adalah sistem cara kerja ataupun bentuk struktur yang pasti. Maka pola belanja konsumen bisa diartikan sebagai bentuk struktur dari kegiatan belanja konsumen yang pasti. Dari pola belanja konsumen inilah yang dapat diprediksi untuk pembuat keputusan strategi yang lebih efektif.

Dalam hal ini Pola memiliki 2 bagian yaitu sebuah Left Hand Side (LHS) dan sebuah Right Hand Side (RHS). LHS adalah sebuah kumpulan dari satu atau beberapa nilai atribut atau item. RHS adalah sebuah atribut atau item tunggal. Sejumlah nilai terdaftar dari tiap pola : [5]

a. Coverage : sejumlah kasus dalam data yang terliputi atau ter-cover oleh pola Left Hand Side (LHS). Misalkan terdapat 1000 kasus dan nilai atribut atau item cover adalah 200 kasus. Nilai coverage-nya adalah 200 dan coverage proportion-nya 200/1000 $=0.2$

b. Right Hand Side (RHS) Coverage : sejumlah kasus dalam data yang terliputi atau ter-cover oleh pola RHS. Misalkan terdapat 1000 kasus dan RHS cover 100 kasus. Nilai coverage-nya 200 dan coverage proportionnya $100 / 1000=0.1$

c. Support : sejumlah kasus dalam data yang terliputi atau ter-cover oleh pola LHS (Left Hand Side) dan RHS (Right Hand Side). Misalkan terdapat 1000 kasus LHS dan RHS tergabung meng-cover 200 kasus. Nilai Support Count-nya adalah 200 dan support proportion-nya adalah $200 / 1000=0.2$

d. Strength : proporsi dari contoh yang ter-cover oleh LHS yang ter-cover juga oleh RHS. Atau sama saja sebagai probabilitas kasus yang memenuhi RHS jika telah memenuhi LHS. Misalkan LHS meng-cover 200 kasus dan RHS meng-cover 50 dari kasus yang ter-cover oleh LHS. Nilai Strength-nya adalah $50 / 200=0.25$

e. Lift : nilai Strength dibagi $R H S$ coverage proportion. Misalkan ada 1000 contoh, LHS meng-cover 200 contoh, RHS meng-cover 100 contoh, dan RHS 
meng-cover 50 dari contoh yang ter-cover LHS. Strength $=50 / 200=0.25$. RHS cover proportion $=$ $100 / 1000=0.1$. Lift $=0.25 / 0.1=2.5$

f.Leverage : sejumlah kasus tambahan yang ter-cover baik itu oleh LHS dan RHS dan dipenuhi jika LHS dan RHS tidak bergantung satu sama lainnya. Misalkan terdapat 1000 kasus, LHS meng-cover 200 kasus, RHS meng-cover 100 kasus, RHS mengcover 50 dari kasus yang ter-cover oleh LHS. Proporsi dari contoh yang ter-cover baik itu oleh LHS dan RHS adalah 50/1000 $=0.05$. Jumlah contoh yang diharapkan ter-cover oleh LHS dan RHS jika mereka tidak saling bergantung satu sama lain $=200 * 100 / 1000=20$. Leverage count $=50-20$ $=30$. Leverage Proportion $=30 / 1000=0.03$ [5]

\section{Data Mining}

\subsection{Tahap-Tahap Data Mining}

Menurut Fayyad (1996), istilah data mining dan knowledge discovery in databases (KDD) sering kali digunakan secara bergantian untuk menjelaskan proses penggalian informasi tersembunyi dalam suatu basis data yang besar. Dan tahapan dalam data mining ini adalah seperti proses KDD yang secara garis besar dapat dijelaskan sebagai berikut :[2]

a. Data Selection

Pemilihan (seleksi) data dari sekumpulan data operasional perlu dilakukan sebelum tahap penggalian informasi dalam KDD dimulai. Data hasil seleksi yang akan digunakan untuk proses data mining. Disimpan dalam suatu berkas, terpisah dari basis data operasional.

b. Pre-processing/ Cleaning

Sebelum proses data mining dapat dilaksanakan, perlu dilakukan proses cleaning pada data yang menjadi fokus KDD. Proses cleaning mencakup antara lain membuang duplikasi data, memeriksa data yang inkonsisten, dan memperbaiki kesalahan pada data, seperti kesalahan cetak (tipografi).

c. Transformation

Coding adalah proses transformasi pada data yang telah dipilih, sehingga sesuai untuk proses data mining..

\section{d. Data Mining}

Data mining adalah proses mencari pola atau informasi menarik dalam data terpilih dengan menggunakan teknik atau metode tertentu.

\section{e. Interpretation/Evaluation}

Pola informasi yang dihasilkan dari proses data mining perlu ditampilkan dalam bentuk yang mudah dimengerti oleh pihak yang berkepentingan. Tahap ini merupakan bagian dari proses KDD yang disebut interpretation.[3]

\section{Association Rule}

Analisis asosiasi atau association rule mining adalah teknik data mining untuk menemukan aturan asosiatif antara suatu kombinasi item. Karena analisis asosiasi menjadi terkenal karena aplikasinya untuk menganalisis isi keranjang belanja di pasar swalayan, analisis asosiasi juga sering disebut market basket analysis (Kusrini dan Luthfi, 2009).[4]

Dalam menentukan suatu association rule, terdapat ukuran yang menyatakan bahwa suatu informasi atau knowledge dianggap menarik (interestingness measure). Ukuran ini didapatkan dari hasil pengolahan data dengan perhitungan tertentu. Untuk mengukur interestingness measure, dapat digunakan variable berikut ini :

\section{a. Support}

Suatu ukuran yang menunjukan berapa besar tingkat dominasi suatu item atau itemset dari keseluruhan transaksi. Ukuran ini menentukan apakah suatu item atau itemset layak dicari confidence-nya (misalnya, dari keseluruhan transaksi yang ada, seberapa besar tingkat dominasi yang menunjukkan bahwa item A dibeli bersamaan dengan item B).

$$
\operatorname{Support}(A)=\frac{\text { Jumlah Transaksi Mengandung } A}{\text { Total Transaksi }}
$$

\section{b. Confidence}

Suatu ukuran yang menunjukan hubungan antar dua item secara conditional (misalnya, seberapa sering item B dibeli jika pelanggan membeli item A).

$$
\text { Confidence }(A \rightarrow B)=\frac{\text { Jumlah TransalsiMengandung } A \text { dan } B}{\text { Jumlah Transalsi Mengandung } A}
$$

\section{Knowledge Discovery in Database (KDD)}

Knowledge Discovery and Data Mining (KDD) adalah proses yang dibantu oleh computer untuk menggali dan menganalisis sejumlah besar himpunan data dan mengekstrak informasi dan pengetahuan yang berguna. Data mining tools memperkirakan perilaku dan tren masa depan, memungkinkan bisnis untuk membuat keputusan yang proaktif dan berdasarkan pengetahuan. Data mining tools mampu menjawab permasalahan bisnis yang secara tradisional terlalu lama untuk diselesaikan. Data mining tools menjelajah database untuk mencari pola tersembunyi, menemukan infomasi yang prediktif yang mungkin dilewatkan para pakar karena berada di luar ekspektasi.[2]

\section{Algoritma FP-Growth}

Algoritma FP-Growth merupakan salah satu alternatif algoritma yang cukup efektif untuk mencari himpunan data yang paling sering muncul (frequent itemset) dalam sebuah kumpulan data yang besar. Algoritma FP-Growth merupakan algoritma Association Rules yang cukup sering dipakai. Algoritma FP-Growth ini dikembangkan dari algoritma apriori. Algoritma apriori menghasilkan kombinasi yang sangat banyak sehingga data yang dihasilkan tidak efisien.[1]

\section{Java Weka}

Weka merupakan API Java yang menyediakan API untuk pengolahan dalam data mining yang berbasis open source dan berengine Java. Weka dikembagkan oleh Universitas Waikato di Selandia Baru dan juga merupakan perangkat lunak gratis yang tersedia dibawah GNU (General Public License). Weka menyediakan penggunaan teknik klasifikasi menggunakan pohon keputusan dengan algoritma J48. Teknik yang digunakan weka adalah classifier.[2]

Menurut situs resmi WEKA (Waikato Environment for Knowledge Analysis), "WEKA adalah kumpulan algoritma pembelajaran mesin untuk tugas-tugas data mining. Algoritma baik dapat diterapkan langsung ke dataset atau disebut dari kode Java itu sendiri. Weka berisi alat untuk data pra-pengolahan, klasifikasi, regresi, clustering, aturan 
asosiasi, dan visualisasi. Hal ini juga cocok untuk mengembangkan skema pembelajaran mesin baru.[6]

\section{METODE PENELITIAN}

\section{Metodologi Penelitian}

Pembuatan analisa pola belanja swalayan daily mart untuk menentukan tata letak barang menggunakan algoritma FP-Growth ini menggunakan metodologi Knowledge

Discovery and Data Mining (KDD

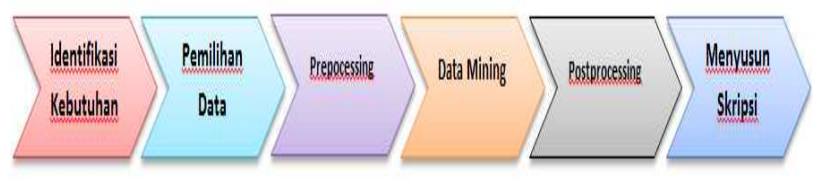

Gambar 1 Metodologi KDD

\section{Tahapan Penelitian}

a. Identifikasi Kebutuhan

Tahap identifikasi dan analisa kebutuhan dilakukan untuk bisa mengetahui apa saja yang dibutuhkan peneliti unutk pengembangan model yang nantinya akan di uji.

b. Pemilihan Data

Dalam hal ini data yang dibutuhkan adalah data transaksi/struk penjualan barang per belanjaan.

c. Preprocessing

Sebelum proses data mining dilakukan, diperlukan proses pendahuluan dan pembersihan data (cleaning) yang merupakan operasi dasar.

d. Mining

Pada tahap ini adalah proses yang esensial dimana metode association rules diterapkan. Data preprocessing yang sudah terbentuk kemudian diproses dengan menggunakan algoritma FP-Growth.

e. Post processing

Pada tahap ini adalah proses visualisasi yang memungkinkan analis untuk mengekspor data dan hasil data mining dari berbagai sudut pandang.

$f$. Menyusun Skripsi

Langkah terakhir pada penelitian ini adalah membuat laporan skripsi.

\section{Lingkungan Perangkat Keras dan Perangkat Lunak}

Perangkat keras yang digunakan pada penelitian ini adalah sebuah Laptop dengan spesifikasi :

- Processor Intel Core i7 4710HQ $3.5 \mathrm{GHz}$

- 4GB Memory

- 1 TB HDD

- Monitor 14"

- Keyboard.

- Printer

Sedangkan perangkat lunak yang digunakan pada penelitian ini adalah :

1. Sistem Operasi Microsoft Windows 7 Home Premium 64-bit.

2. Microsoft Exel 2007 sebagai database.

3. Java Weka versi 3.7.4 untuk analisa dengan menggunakan algoritma FP-Growth.

4. Notepad ++

\section{IV.HASIL DAN PEMBAHASAN}

1. Data

Dalam penelitian ini digunakan data mentah yaitu data transaksi minimarket dalam 1 bulan dengan jumlah transaksi 4234 data transaksi.

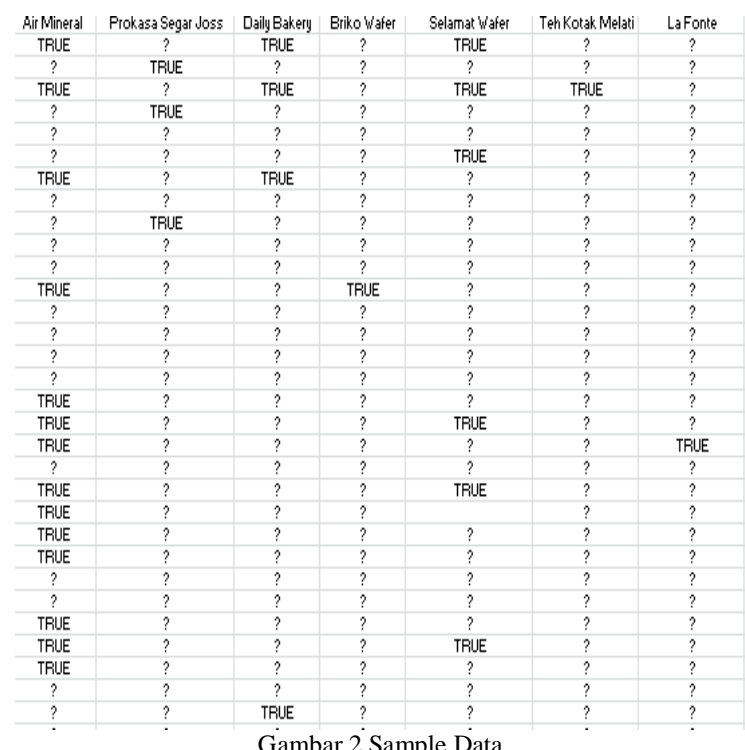

Dalam table diatas, baris paling atas menunjukan itemitem yang dijual, sementara baris selanjutnya adalah baris transaksi pembelian konsumen yang dalam 1 baris itu menunjukan satu kali transaksi. Dan dalam kolom transaksi (true) memiliki arti ada pembelian/transaksi dari konsumen yang membeli item tersebut, kode (?) yang berarti tidak ada pembelian/transaksi dari konsumen untuk item tersebut.

\section{Hasil FP-Growth Menggunakan Java Weka}

Berdasarkan penelitian di swalayan Daily Mart ini maka data transaksi yang didapat dan diolah menggunakan software Java Weka 3.7.4. Dalam penggunaan software ini hal pertama yang dilakukan adalah dengan melakukan penginputan data dalam Microsoft Word. Kemudian peniliti melanjutkan dalam pembuatan data untuk penginputan dalam software weka, tapi sebelumnya data yang digunakan sebagai masukan harus data dengan format *.arff atau *.csv. selanjutnya data yang sudah terformat dibuka melalui notepad untuk mengatur data yang tadinya masih acak dan belum teratur untuk melanjutkan proses pencarian.

Pada tahap ini juga sebelum menemukan hasil akhir, hal yang dilakukan pertama adalah dengan melakukan proses mining untuk masuk pada tahap preprocessing dan untuk bisa menemukan hasil dari frequent pattern growth. Setelah dillakukan proses pencarian pola dengan menggunakan algoritma FP-Growth dan Association Rule pada software WEKA ini, maka tahap selanjutnya adalah proses penggalian frequent itemset. Pada hal ini data yang sudah diolah merupakan proses pemilihan yang dilakukan oleh pengguna software WEKA.

Dan dibawah ini adalah hasil yang didapat menggunakan software WEKA 3.7.4 yang sudah diterjemahkan berdasarkan confidence yang paling strong atau berdasarkan pembeliian yang paling sering dibeli secara bersamaan. 


TABELI 1. HASIL PENCARIAN POLA CONF 0.94
\begin{tabular}{|l|c|c|c|c|}
\hline \multicolumn{1}{|c|}{ Rule } & Conf & Lift & Lev & Conv \\
\hline AIR MINERAL => & 0.94 & 1.3 & 0.02 & 4.33 \\
TISSUE / SILVERQUEEN & & & & \\
/ SELAMAT WAFER / \\
KRIPIK / BRIKO WAFER & & & & \\
\hline AIR MINERAL => & 0.94 & 1.3 & 0.02 & 4.2 \\
TISSUE / SELAMAT & & & & \\
WAFER / KRIPIK / & & & & \\
SALTCHEESE & & & & \\
\hline
\end{tabular}

Pada table di atas dengan nilai confidence 0.94 dapat diketahui bahwa konsumen daily mart ini jika membeli air mineral maka akan membeli tissue, silverqueen, selamat wafer, kripik, dan briko wafer dengan nilai pada umumnya lift 1.3 untuk nilai yang sudah tercover contoh strength $=$ $50 / 200=0.25$. RHS cover proportion $=100 / 1000=0.1$. Lift $=0.25 / 0.1=2.5$. table diatas juga menjelaskan bahwa nilai Lev 0.02 ini adalah untuk jumlah kasus tambahan. Conv pada table diatas untuk nilai jumlah kasus dalam data yang terliputi. Dan pada umumnya untuk hasil conf, lift, lev dan conv pada table diatas otomatis terhitung dalam software Weka ini.

TABEL 2. HASIL PENCARIAN POLA CONF 0.93

\begin{tabular}{|l|c|c|c|c|}
\hline \multicolumn{1}{|c|}{ Rule } & Conf & Lift & Lev & Conv \\
\hline $\begin{array}{l}\text { TISSUE / SILVERQUEEN / } \\
\text { KRIPIK / SALTCHEESE => } \\
\text { AIR MINERAL }\end{array}$ & 0.93 & 1.3 & 0.02 & 4.11 \\
\hline $\begin{array}{l}\text { TISSUE / KOPI / KRIPIK / } \\
\text { BRIKO WAFER => AIR } \\
\text { MINERAL }\end{array}$ & 0.93 & 1.3 & 0.03 & 4.11 \\
\hline $\begin{array}{l}\text { TISSUE / SILVERQUEEN / } \\
\text { KOPI / SALTCHEESE => } \\
\text { AIR MINERAL }\end{array}$ & 0.93 & 1.29 & 0.02 & 3.93 \\
\hline $\begin{array}{l}\text { TISSUE / SELAMAT } \\
\text { WAFER / BRIKO WAFER / } \\
\text { FRUIT TEA => AIR } \\
\text { MINERAL }\end{array}$ & 0.93 & 1.29 & 0.02 & 3.92 \\
\hline $\begin{array}{l}\text { TISSUE / KRIPIK / THE } \\
\text { KOTAK MELATI / BRIKO } \\
\text { WAFER => AIR MINERAL }\end{array}$ & 0.93 & 1.29 & 0.02 & 3.9 \\
\hline $\begin{array}{l}\text { KRIPIK / TISSUE / } \\
\text { SALTCHEESE => AIR } \\
\text { MINERAL }\end{array}$ & 0.93 & 1.29 & 0.03 & 3.9 \\
\hline $\begin{array}{l}\text { SILVERQUEEN / KRIPIK / } \\
\text { BRIKO WAFER => } \\
\text { TISSUE / AIR MINERAL }\end{array}$ & 0.93 & 1.29 & 0.03 & 3.89 \\
\hline $\begin{array}{l}\text { TISSUE / SILVERQUEEN / } \\
\text { KOPI / SELAMAT WAFER } \\
\text { / KRIPIK => AIR } \\
\text { MINERAL }\end{array}$ & 0.93 & 1.29 & 0.03 & 3.84 \\
\hline $\begin{array}{l}\text { TISSUE / SELAMAT } \\
\text { WAFER / KRIPIK / BRIKO } \\
\text { WAFER => AIR MINERAL }\end{array}$ & 0.93 & 1.29 & 0.03 & 3.84 \\
\hline $\begin{array}{l}\text { TISSUE / KOPI / } \\
\text { SELAMAT WAFER / } \\
\text { BRIKO WAFER => AIR } \\
\text { MINERAL }\end{array}$ & 0.93 & 1.29 & 0.03 & 3.81 \\
\hline $\begin{array}{l}\text { KRIPIK / BRIKO WAFER / } \\
\text { FRUIT TEA / TISSUE => } \\
\text { AIR MINERAL }\end{array}$ & 0.93 & 1.29 & 0.02 & 3.8 \\
\hline
\end{tabular}

\begin{tabular}{|c|c|c|c|c|}
\hline $\begin{array}{l}\text { KOPI / SALTCHEESE / } \\
\text { AIR MINERAL => TISSUE }\end{array}$ & 0.93 & 1.29 & 0.03 & 3.81 \\
\hline
\end{tabular}

Table berikutnya dengan nilai confidence 0.93 dapat diketahui bahwa konsumen daily mart ini jika membeli tissue maka akan membeli silverqueen, kripik, saltcheese dan air mineral juga. Dengan nilai pada umumnya lift 1.29 untuk nilai yang sudah tercover atau nilai confidence paling tinggi, contoh strength $=50 / 200=0.25$. RHS cover proportion $=100 / 1000=0.1$. Lift $=0.25 / 0.1=2.5$. table diatas juga menjelaskan bahwa nilai Lev 0.02 ini adalah untuk jumlah kasus tambahan. Conv pada table diatas untuk nilai jumlah kasus dalam data yang terliputi. Dan pada umumnya untuk menemukan hasil dari hasil conf, lift, lev dan conv pada table diatas otomatis terhitung dalam software Weka ini.

TABEL 3. HASIL PENCARIAN POLA CONF 0.92

\begin{tabular}{|c|c|c|c|c|}
\hline Rule & Conf & Lift & Lev & Conv \\
\hline $\begin{array}{l}\text { TISSUE / SILVERQUEEN / } \\
\text { SELAMAT WAFER / } \\
\text { SALTCHEESE => AIR } \\
\text { MINERAL }\end{array}$ & 0.92 & 1.29 & 0.02 & 3.64 \\
\hline $\begin{array}{l}\text { TISSUE / KOPI / THE } \\
\text { KOTAK MELATI / BRIKO } \\
\text { WAFER => AIR MINERAL }\end{array}$ & 0.92 & 1.29 & 0.02 & 3.64 \\
\hline $\begin{array}{l}\text { TISSUE / KOPI / } \\
\text { SELAMAT WAFER / } \\
\text { KRIPIK => AIR MINERAL }\end{array}$ & 0.92 & 1.29 & 0.03 & 3.66 \\
\hline $\begin{array}{l}\text { TISSUE / SILVERQUEEN / } \\
\text { TEPUNG TERIGU / KOPI / } \\
\text { KRIPIK => AIR MINERAL }\end{array}$ & 0.92 & 1.28 & 0.02 & 3.63 \\
\hline $\begin{array}{l}\text { TISSUE / TEPUNG } \\
\text { TERIGU / SALTCHEESE } \\
\text { => AIR MINERAL }\end{array}$ & 0.92 & 1.28 & 0.02 & 3.64 \\
\hline $\begin{array}{l}\text { TISSUE / BRIKO WAFER / } \\
\text { RITZ CRACKERS => AIR } \\
\text { MINERAL }\end{array}$ & 0.92 & 1.28 & 0.02 & 3.63 \\
\hline $\begin{array}{l}\text { TISSUE / SILVERQUEEN / } \\
\text { SELAMAT WAFER / } \\
\text { KRIPIK / THE KOTAK } \\
\text { MELATI => AIR } \\
\text { MINERAL }\end{array}$ & 0.92 & 1.28 & 0.02 & 3.62 \\
\hline $\begin{array}{l}\text { TISSUE / SIVERQUEEN / } \\
\text { SELAMAT WAFER / RITZ } \\
\text { CRACKERS => AIR } \\
\text { MINERAL }\end{array}$ & 0.92 & 1.28 & 0.02 & 3.6 \\
\hline $\begin{array}{l}\text { TISSUE / TEPUNG } \\
\text { TERIGU / SELAMAT } \\
\text { WAFER / FRUIT TEA => } \\
\text { AIR MINERAL }\end{array}$ & 0.92 & 1.28 & 0.02 & 3.6 \\
\hline $\begin{array}{l}\text { TISSUE / SILVERQUEEN / } \\
\text { TEPUNG TERIGU / } \\
\text { SELAMAT WAFER / } \\
\text { KRIPIK => AIR MINERAL }\end{array}$ & 0.92 & 1.28 & 0.02 & 3.6 \\
\hline $\begin{array}{l}\text { TISSUE / SILVERQUEEN / } \\
\text { KOPI / BRIKO WAFER => } \\
\text { AIR MINERAL }\end{array}$ & 0.92 & 1.28 & 0.03 & 3.59 \\
\hline $\begin{array}{l}\text { TISSUE / SILVERQUEEN / } \\
\text { KRIPIK / NU GREEN TEA } \\
\text { => AIR MINERAL }\end{array}$ & 0.92 & 1.28 & 0.03 & 3.59 \\
\hline $\begin{array}{l}\text { TISSUE / TEPUNG } \\
\text { TERIGU / SELAMAT }\end{array}$ & 0.92 & 1.28 & 0.02 & 3.57 \\
\hline
\end{tabular}


WAFER / NU GREEN TEA $\Rightarrow$ AIR MINERAL

Table berikutnya dengan nilai confidence 0.92 dapat diketahui bahwa konsumen daily mart ini jika membeli tissue maka akan membeli silverqueen, kripik, saltcheese dan air mineral juga. Dengan nilai pada umumnya lift 1.28 untuk nilai yang sudah tercover atau nilai confidence paling tinggi, contoh strength $=50 / 200=0.25$. RHS cover proportion $=100 / 1000=0.1$. Lift $=0.25 / 0.1=2.5$. table diatas juga menjelaskan bahwa nilai Lev 0.02 ini adalah untuk jumlah kasus tambahan. Conv pada table diatas untuk nilai jumlah kasus dalam data yang terliputi. Dan pada umumnya untuk menemukan hasil dari hasil conf, lift, lev dan conv pada table diatas otomatis terhitung dalam software Weka ini.

\section{BAB V \\ KESIMPULAN DAN SARAN}

\section{Kesimpulan}

Berdasarkan tahap-tahap penelitian yang sudah dilakukan sebelumnya, maka dapat ditarik kesimpulan sebagai berikut:

- Jika membeli air mineral maka membeli tissue, silverqueen, selamat wafer, kripik dan briko wafer memiliki nilai confidence sebesar 0.94 yang memiliki arti tingkat kepastian konsumen membeli air mineral bersama tissue bernilai 0.94. Nilai confidence merupakan hasil banyaknya transaksi yang dibeli secara bersamaan.

- Didapatkan aturan seperti ini maka untuk pemasaran dapat menggunakan aturan tersebut dalam membuat strategi untuk meningkatkan penjualan.

- Dengan menggunakan algoritma FP-Growth dan bantuan dari software Weka didapatkan hasil berupa aturan (rules) yang merupakan kumpulan frequent itemset dengan nilai confidence yang tinggi.

\section{Saran}

- Penelitian selanjutnya bisa dilakukan dalam 21 musim (kemarau dan hujan) agar bisa mendapatkan pola perbandingan.

- Data yang diolah ditambah dengan data yang lebih bervariasi agar knowledge yang dihasilkan lebih menarik.

- Penelitian selanjutnya bisa mencoba menggunakan algoritma data mining lain sehingga dapat dicari algoritma yang lebih efisien dan efektif

\section{DAFTAR PUSTAKA}

[1] Erwin, 2009. Analisis Market Basket Dengan Algoritma Apriori dan FP-Growth

[2] Fayyad, Usama. 1996. Advances in Knowledge Discovery and Data Mining. MIT Press.

[3] Herbert A. Edelstein (October 8, 1999) Introduction to Data Mining and Knowledge Discovery Third Edition.
[4] Kusrini dan Luthfi, E.T, 2009, Algoritma Data Mining, Andi Offset, Yogyakarta

[5] Tugas Besar Sistem Informasi Manajemen Software Weka Waikato Environment. https://wordpress.com

[6] WEKA Online Documentation, University of Waikato, New Zealand. http://www.cs.waikato.ac.nz/ml/weka/. Diakses terakhir tanggal 28.

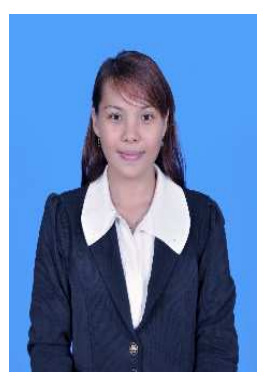

Sekilas dari penulis dengan nama lengkap Kezia Sumangkut, lahir pada tanggal 02 September 1992 di Manado. Anak ke-2 dari 2 bersaudara. Dengan pendidikan pertama di Taman Kanak-Kanak GMIM Sola Gratia, kemudian melanjutkan ke SD Gmim 8 Manado, melanjutkan ke SMP Advent 01 Tikala, dan pada tahun 2007 melanjutkan ke SMA N 7 Manado.

Setelah lulus sekolah tingkat atas pada tahun 2010 penulis melanjutkan ke Perguruan Tinggi tepatnya di Universitas Sam Ratulangi Manado, Fakultas Teknik, Jurusan Elektro, Program Studi Teknik Informatika. Penulis membuat skripsi untuk memenuhi syarat sarjana (S1) dengan judul Analisa Pola Belanja Swalayan Daily Mart Untuk Menentukan Tata Letak Barang Menggunakan Algoritma FP-Growth yang di bimbing oleh dua dosen Teknik Informatika yaitu Arie Lumenta, ST, MT dan Virginia Tulenan, S.Kom, MTI sehingga pada tanggal 04 Maret 2016 penulis resmi lulus di Teknik Informatika Universitas Sam Ratulangi Manado. 